\title{
Trametes robiniophila may induce apoptosis and inhibit MMPs expression in the human gastric carcinoma cell line MKN-45
}

\author{
XUENING JI ${ }^{1 *}$, CHUNXIA PAN $^{2 *},{\text { XIAOWEN } I^{1}}^{1}$, YUNBIN GAO $^{1}$, LU XIA $^{1}$, \\ XIULIAN QUAN ${ }^{1}$, JINYAN LV $^{1}$ and RUOYU WANG ${ }^{1}$ \\ ${ }^{1}$ Department of Oncology, Affiliated Zhongshan Hospital of Dalian University, Dalian, Liaoning 116001; \\ ${ }^{2}$ Department of Oncology, The Third People's Hospital of Dalian, Dalian, Liaoning 116033, P.R. China
}

Received May 12, 2015; Accepted August 25, 2016

DOI: $10.3892 / \mathrm{ol} .2016 .5517$

\begin{abstract}
Gastric carcinoma (GC) is one of the most common malignant tumors and is mainly treated by invasive surgeries. The present study aimed to investigate the treatment potential of Trametes robiniophila on GC using the human GC cell line MKN-45. Cells were incubated with Trametes robiniophila at a concentration of 0,5 and $10 \mathrm{mg} / \mathrm{ml}$ for $24 \mathrm{~h}$. The apoptosis of the cell line was examined with acridine orange/ethidium bromide staining and flow cytometry. The expression of B-cell lymphoma (Bcl)-2, Fas, caspase-3, matrix metalloproteinase (MMP)-2 and MMP-9 was analyzed using reverse transcription-polymerase chain reaction and western blotting. With increasing drug concentrations, the proportion of apoptotic and necrotic cells increased. For a certain concentration, the apoptotic ratio also increased with increasing response times. Compared with the control group, the Bcl-2, MMP-2 and MMP-9 expression levels in the MKN-45 cell line decreased, while the expression levels of Fas and caspase- 3 increased $(\mathrm{P}<0.05)$, and the expression patterns were strengthened with increasing drug concentrations. The present study revealed that Trametes robiniophila had treatment potential on GC, and it may act on gastric cells through apoptotic induction and MMPs expression inhibition. Based on the present results, Trametes robiniophila may be considered as an alternative approach for noninvasive therapy of GC. However, future studies should be performed to clarify this further.
\end{abstract}

\section{Introduction}

Gastric carcinoma (GC) remains a major health issue worldwide, with 1 million newly diagnosed cases and 700,000 mortalities each year (1). Occurrence of GC varies with geography, and in

Correspondence to: Professor Ruoyu Wang, Department of Oncology, Affiliated Zhongshan Hospital of Dalian University, 6 Jiefang Road, Dalian, Liaoning 116001, P.R. China

E-mail: ruoyuwang14@163.com

*Contributed equally

Key words: apoptosis, antitumor, gastric carcinoma, matrix metalloproteinases, Trametes robiniophila
Asia or the Pacific Islands, the incidences and mortality rates of GC can be twice as high as those in Western countries (2). GC is considered as a multifactorial disease due to numerous inherited and environmental factors, including genetic background, infectious agents and dietary habits (3). Surgery remains the only curative therapy for GC treatment, and perioperative and adjuvant chemotherapy can improve the outcome $(4,5)$. However, no clear superiority of one strategy over others has been observed, and serious side effects and dose-limiting toxicities of chemotherapy treatments are common (6). In addition, $>50 \%$ of resected GC patients experience reccurrence and metastases (7). Safe, natural and non-toxic agents that can interfere with the essential steps of cancer development are increasingly used for cancer therapy $(8,9)$. Traditional Chinese medicines (TCMs) have recently drawn great attention as possible anticancer agents with few side effects.

Trametes robiniophila Murr. (Huaier) is a fungal species in China that has been applied in TCM for $>1,600$ years (10). In recent years, the antitumor effect of Huaier has been demonstrated, and Trametes robiniophila extracted from the fungus in hot water to eliminate the free proteins and amino acids has been increasingly applied in clinical cancer therapy $(10,11)$. The major active ingredient of Trametes robiniophila is proteoglycan, including $41.53 \%$ polysaccharides, $12.93 \%$ amino acids and $8.72 \%$ water (12). However, the inhibition effect on cancer of proteoglycan and other isolated ingredients was much lower than that of Trametes robiniophila $(13,14)$. The antitumor effect of Trametes robiniophila involves various mechanisms, including induction of apoptosis, anti-angiogenesis, drug resistance reversal, anti-metastasis and system immune activation (15). The current study attempted to investigate the antitumor effect of Trametes robiniophila on GC using the human GC cell line MKN-45. The apoptosis of the cell line was examined with acridine orange (AO)/ethidium bromide (EB) staining and flow cytometry, and the expression level of molecules involved in the apoptotic and metastatic processes of tumors were analyzed using reverse transcription-polymerase chain reaction (RT-PCR) and western blotting.

\section{Materials and methods}

Preparation of Trametes robiniophila. Trametes robiniophila was purchased from Qidong Gaitianli Pharmaceutical Co., Ltd. 
Table I. Detailed information of primers.

\begin{tabular}{llcc}
\hline Gene & \multicolumn{1}{c}{ Sequence $\left(5^{\prime}-{ }^{\prime}\right)$} & $\mathrm{T}_{\mathrm{a}}\left({ }^{\circ} \mathrm{C}\right)$ & Length (bp) \\
\hline Bcl-2 & Forward GCTGTCGCAGAGGGGCTAC & 55 & 375 \\
Fas & $\begin{array}{l}\text { Reverse ATCCTCCCCAGTTCACCC } \\
\text { Forward CTGCCATAAGCCCTGTCCTC }\end{array}$ & 56 & 316 \\
Caspase-3 & Reverse GGTGTTGCTGGTGAGTGTGC & 561 \\
MMP-2 & Forward CAAATGGACCTGTTGACCTGA & 56 & 278 \\
MMP-9 & Reverse ATTCTGTTGCCACCTTTCGG & 55 & 101 \\
$\beta$-actin & Forward GATGCCGCCTTTAACTGG & 54 & 183 \\
& Foverse TCAGCAGCCTAGCCAGTCG & 55 & \\
\hline
\end{tabular}

MMP, matrix metalloproteinase; $\mathrm{Bcl}$, B-cell lymphoma; $\mathrm{T}_{\mathrm{a}}$, annealing temperature.

(Qidong, China). Trametes robiniophila $(1.0 \mathrm{~g})$ was dissolved in $10 \mathrm{ml}$ RPMI-1640 medium (Gibco; Thermo Fisher Scientific, Inc., Waltham, MA, USA) and sterilized using a $0.22-\mu \mathrm{m}$ filter to obtain the $100 \mathrm{mg} / \mathrm{ml}$ stock solution that was suitable for long-term storage at $37^{\circ} \mathrm{C}$.

Preparation of the MKN-45 cell line. The GC cell line MKN-45 was obtained from the Shanghai Institute of Cellular Biology of Chinese Academy of Sciences (Shanghai, China) and was routinely cultured in RPMI-1640 medium supplemented with $10 \%$ fetal bovine serum (Hangzhou Sijiqing Bioengineering Material Co., Ltd., Hangzhou, Zhejiang, China), 100 U/ml penicillin and $100 \mathrm{mg} / \mathrm{ml}$ streptomycin (Biyuntian, Jiangsu, China) under the conditions of $5 \% \mathrm{CO}_{2}$ at $4{ }^{\circ} \mathrm{C}$.

AO/EB staining to detect apoptosis. The cell concentrations were adjusted to $5 \times 10^{4}$ cells $/ \mathrm{ml}$, and cells were incubated on slides in 24-well plates for $24 \mathrm{~h}$. For experimental use, the Trametes robiniophila stock solution was diluted to a final concentration of 5 or $10 \mathrm{mg} / \mathrm{ml}$, with $0 \mathrm{mg} / \mathrm{ml}$ serving as control. AO/EB (4 $\mu \mathrm{g}$; Amresco, LLC, Solon, OH, USA) was added to each well after $48 \mathrm{~h}$. The apoptosis of the cell line was detected with a fluorescence microscope at $510 \mathrm{~nm}$. Each treatment was represented by three replicates.

Flow cytometric analysis of apoptosis. Cells were cultured with Trametes robiniophila for 24, 48 and $72 \mathrm{~h}$ as aforementioned. Annexin V-fluorescein isothiocyanate (5 $\mu$ l; Kaiji Bio Co., Nanjing, China) was added to different wells and incubated for $10 \mathrm{~min}$ at room temperature. The cells were resuspended with $1 \mathrm{X}$ binding buffer, and $5 \mu \mathrm{l}$ propidium iodide (PI) was added. Next, the apoptosis of the cells was analyzed by flow cytometry. Each treatment was represented by three replicates.

$R T-P C R$. Total RNA was isolated from cells treated with Trametes robiniophila for $24 \mathrm{~h}$ using the TRIzol reagent (Invitrogen; Thermo Fisher Scientific, Inc.) (16). RT-PCR was used to detect the gene expression level of matrix metalloproteinase (MMP)-2, MMP-9, B-cell lymphoma (Bcl)-2, Fas, caspase-3 and the reference gene $\beta$-actin. Primers and annealing temperature information is shown in Table I. The RNA was reversely transcribed into complementary DNA using an RT-PCR kit (Thermo Fisher Scientific, Inc.), and the final reaction mixture (20 $\mu \mathrm{l})$ contained $4 \mu \mathrm{l}$ of $5 \mathrm{X}$ reaction buffer, $1 \mu \mathrm{l}$ RNase inhibitor, $1 \mu \mathrm{l}$ oligo(dT) $)_{18}$ primer, $2 \mu 110 \mathrm{mM}$ deoxynucleotides, $1 \mu 1$ Moloney-murine leukemia virus reverse transcriptase, $2 \mu \mathrm{l}$ RNA template and $9 \mu \mathrm{l}$ double distilled $\mathrm{H}_{2} \mathrm{O}$. The thermal cycling parameters for the amplification were as follows: A denaturation step at $95^{\circ} \mathrm{C}$ for $3 \mathrm{~min}$, followed by 30 cycles at $95^{\circ} \mathrm{C}$ for $15 \mathrm{sec}$, the annealing temperature indicated in Table I for $30 \mathrm{sec}$ and $72^{\circ} \mathrm{C}$ for $45 \mathrm{sec}$. The RT-PCR products were semi-quantified with the UVP Gel Imaging System (UVP, Inc., Upland, CA, USA).

Western blot analysis. The cells and Trametes robiniophila were cultured as aforementioned. Total protein was extracted from the cells using a $400 \mu \mathrm{l}$ single detergent lysis buffer (including phenylmethylsulfonyl fluoride) and radioimmunoprecipitation buffer (Sangon Biotech, Shanghai, China). The lysis mixture was then added to a homogenizer, and centrifuged at $13,500 \times g$ and $4^{\circ} \mathrm{C}$ for $5 \mathrm{~min}$. The supernatant was subpackaged into Eppendorf tube and stored at $-20^{\circ} \mathrm{C}$. The extracts were boiled with loading buffer for $5 \mathrm{~min}$ and then subjected to sodium dodecyl sulfate-polyacrylamide gel electrophoresis on $10 \%$ gels. Targeted proteins were transferred onto polyvinylidene difluoride membranes. The membranes were washed with Tris-buffered saline containing Tween 20 three times, for $20 \mathrm{~min}$ each time. Then, the membranes were incubated overnight with antibodies against Bcl-2 (catalog no. 15071), caspase-3 (catalog no. 9668) and Fas (catalog no. 8023) (all Cell Signaling Technology, Inc., Danvers, MA, USA) at $4^{\circ} \mathrm{C}$. Following an additional three washes, anti-mouse immunoglobulin $\mathrm{G}$, horseradish peroxidase-linked secondary antibodies (catalog no. 7076; 1:3,000 dilution; Cell Signaling Technology, Inc.) were added and incubated at room temperature for $1 \mathrm{~h}$. Upon three final washes, the blots were developed using Beyo ECL Plus reagent (Beyotime Institute of Biotechnology, Haimen, China) and the results were detected in the 

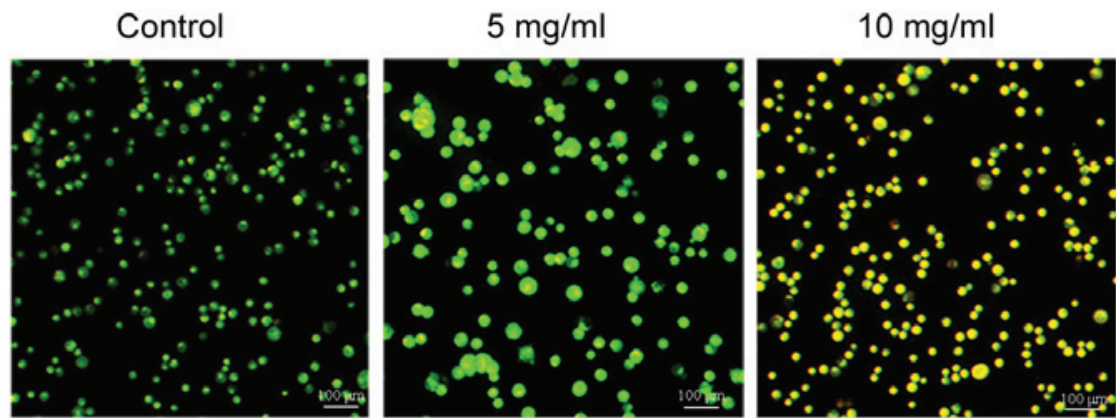

Figure 1. Morphological changes in MKN-45 cells treated with Trametes robiniophila (magnification, $\mathrm{x} 100$ ). Green coloration represents normal cells with an intact structure; yellow coloration represents apoptotic cells with an irregular morphology; and red coloration represents necrotic cells.
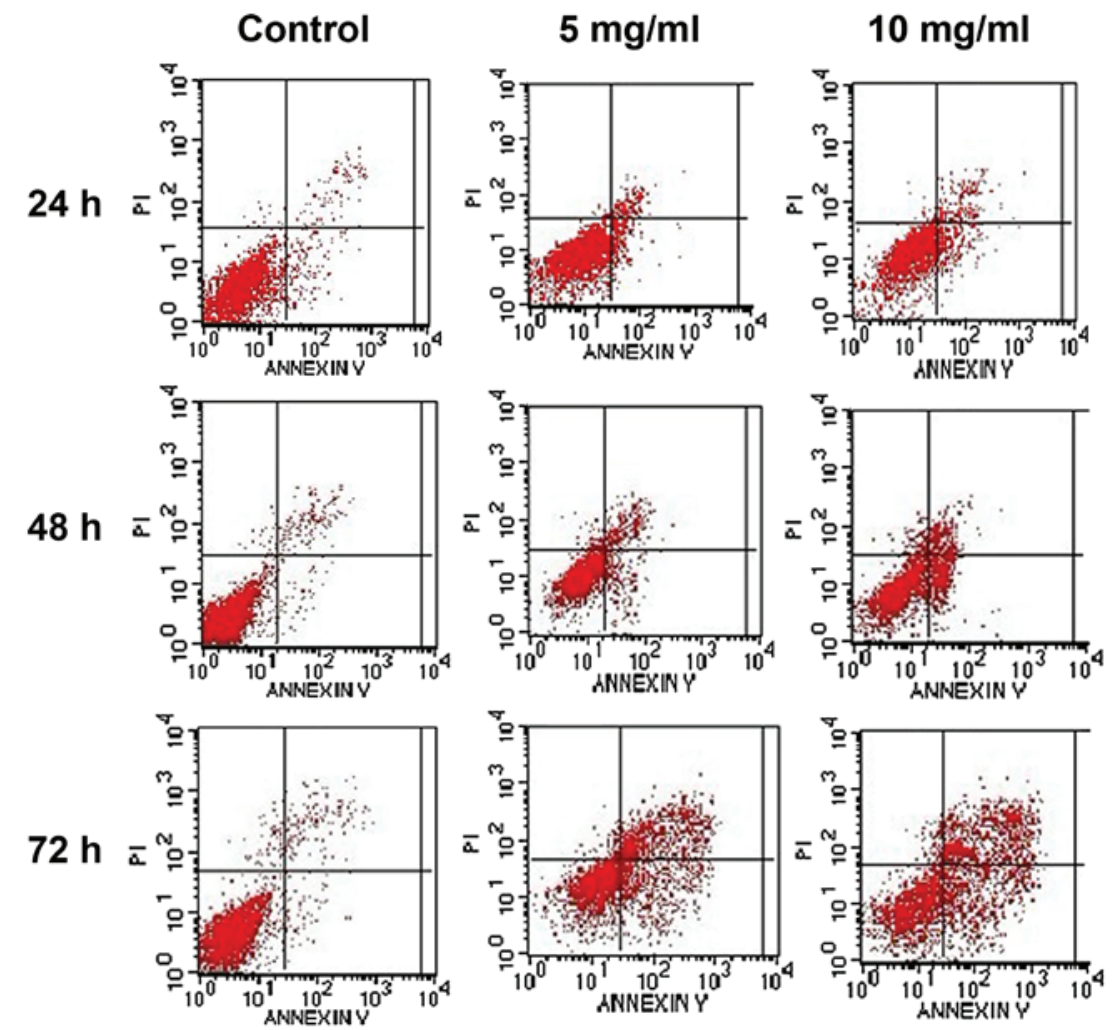

Figure 2. Flow cytometric analysis of Trametes robiniophila-induced apoptosis in the gastric carcinoma cell line MKN-45. PI, propidium iodide.

UVP Gel Imaging System. $\beta$-actin was used as reference. The expression levels were calculated with Quantity One software (Bio-Rad Laboratories, Inc., Hercules, CA, USA).

Statistical analysis. All the data were expressed as the mean \pm standard deviation. Differences between the groups were calculated using one-way analysis of variance. $\mathrm{P}<0.05$ was considered to indicate a statistically significant difference. All statistical analyses were conducted using SPSS version 16.0 (SPSS, Inc., Chicago, IL, USA).

\section{Results}

Cell apoptosis is induced by Trametes robiniophila. Morphological changes in the human GC cell line MKN-45 following treatment with different concentrations of Trametes robiniophila $(0,5$ and $10 \mathrm{mg} / \mathrm{ml})$ for $24 \mathrm{~h}$ are shown in
Fig. 1. Compared with the control group, the majority of the Trametes robiniophila-treated cancer cells became enlarged and irregular-shaped, and exhibited vacuolated changes in the cytoplasm. These morphological changes demonstrated cell damage subsequent to Trametes robiniophila treatment. MKN-45 cells treated with $5 \mathrm{mg} / \mathrm{ml}$ Trametes robiniophila were yellow-dyed, indicating the occurrence of apoptosis (Fig. 1).

Flow cytometry was used to detect intact cells, early apoptotic cells, late apoptotic cells and dead cells. Following treatment with Trametes robiniophila, the cell death rate [as indicated by the upper right (UR) quadrant, which represents the percentage of cells in advanced-stage apoptosis] and the early apoptosis rate [as indicated by the lower right (LR) quadrant, which represents the percentage of cells in prophase apoptosis] of the MKN-45 cell line increased in a time- and dose-dependent manner (Fig. 2). 
Table II. Proportion of apoptotic cells in the MKN-45 cell line.

\begin{tabular}{lccr}
\hline & \multicolumn{3}{c}{ MKN-45 } \\
\cline { 2 - 4 } Apoptotic cells (\%) & $24 \mathrm{~h}$ & $48 \mathrm{~h}$ & $72 \mathrm{~h}$ \\
\hline Control & 6.5 & 7.3 & 7.5 \\
$5 \mathrm{mg} / \mathrm{ml}$ & $14.6^{\mathrm{a}}$ & $18.3^{\mathrm{a}}$ & $50.2^{\mathrm{a}}$ \\
$10 \mathrm{mg} / \mathrm{ml}$ & $18.0^{\mathrm{a}}$ & $24.5^{\mathrm{a}}$ & $58.0^{\mathrm{a}}$ \\
\hline
\end{tabular}

${ }^{\mathrm{a}} \mathrm{P}<0.05$ vs. the control group.

Table III. Expression changes in MMP-2, MMP-9, Bcl-2, Fas and caspase- 3 genes induced by Trametes robiniophila in the MKN-45 cell line.

\begin{tabular}{llll}
\hline & \multicolumn{3}{c}{ MKN-45 } \\
\cline { 2 - 4 } Gene & Control & $5 \mathrm{mg} / \mathrm{ml}$ & $10 \mathrm{mg} / \mathrm{ml}$ \\
\hline MMP-2 & $0.64 \pm 0.02$ & $0.49 \pm 0.01^{\mathrm{a}}$ & $0.36 \pm 0.02^{\mathrm{a}, \mathrm{b}}$ \\
MMP-9 & $0.71 \pm 0.01$ & $0.54 \pm 0.02^{\mathrm{a}}$ & $0.47 \pm 0.02^{\mathrm{a}}$ \\
Bcl-2 & $1.20 \pm 0.06$ & $0.83 \pm 0.05^{\mathrm{a}}$ & $0.64 \pm 0.05^{\mathrm{a}, \mathrm{b}}$ \\
Fas & $0.67 \pm 0.06$ & $0.83 \pm 0.06^{\mathrm{a}}$ & $0.90 \pm 0.04^{\mathrm{a}}$ \\
Caspase-3 & $0.65 \pm 0.01$ & $0.70 \pm 0.03^{\mathrm{a}}$ & $0.99 \pm 0.08^{\mathrm{a}, \mathrm{b}}$ \\
\hline
\end{tabular}

${ }^{\mathrm{a}} \mathrm{P}<0.05$ vs. the control group; ${ }^{\mathrm{b}} \mathrm{P}<0.05$ vs. cells treated with $5 \mathrm{mg} / \mathrm{ml}$ Trametes robiniophila. MMP, matrix metalloproteinase; Bcl, B-cell lymphoma.

Apoptotic cells (as indicated by the sum of the UR and LR quadrants, which represents the percentage of cells in all apoptosis stages) of the MKN-45 cell line were significantly different from those of the control group after being exposed to Trametes robiniophila for 24,48 and $72 \mathrm{~h}$ at drug concentrations of 5 and $10 \mathrm{mg} / \mathrm{ml}$ (all $\mathrm{P}<0.001)$ (Table II).

Trametes robiniophila significantly influences the transcription of MMP-2, MMP-9, Bcl-2, Fas and caspase-3. The expression of MMP-2, MMP-9, Bcl-2, Fas and caspase-3 was significantly influenced by Trametes robiniophila. Analysis of the optical density value revealed that, for the MKN-45 cell line, the expression of MMP-2, MMP-9 and Bcl-2 was significantly downregulated (at $5 \mathrm{mg} / \mathrm{ml}$ and $10 \mathrm{mg} / \mathrm{ml}$, all $\mathrm{P}<0.001$ vs. control; at $10 \mathrm{mg} / \mathrm{ml}, \mathrm{P}<0.001$, $\mathrm{P}=0.003$ and $\mathrm{P}=0.007$ vs. $5 \mathrm{mg} / \mathrm{ml}$ for MMP-2, MMP-9 and Bcl-2, respectively), while the expression of Fas and caspase-3 was upregulated (at $5 \mathrm{mg} / \mathrm{ml}, \mathrm{P}=0.326$ and $\mathrm{P}=0.100$ vs. control for Fas and caspase-3, respectively; at $10 \mathrm{mg} / \mathrm{ml}, \mathrm{P}<0.001$ and $\mathrm{P}=0.020$ vs. control, and $\mathrm{P}=0.017$ and $\mathrm{P}=0.028$ vs. $5 \mathrm{mg} / \mathrm{ml}$ for Fas and caspase-3, respectively) (Table III). The regulation was dose-dependent.

Trametes robiniophila significantly influences the protein expression of Bcl-2, Fas and caspase-3. The production of Fas and caspase-3 was enhanced following treatment with Trametes robiniophila in the MKN-45 cell line; however, the
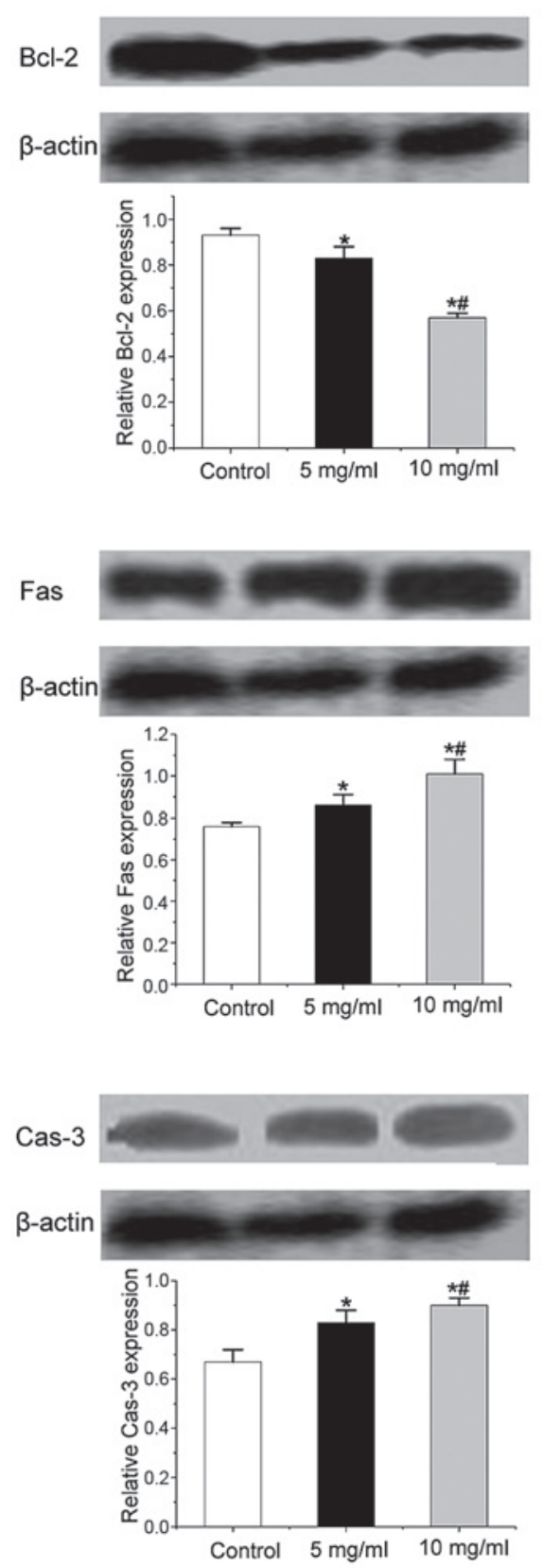

Figure 3. Influence of Trametes robiniophila on the protein expression of Bcl-2, Fas and Cas-3 in the gastric carcinoma cell line MKN-45. ${ }^{*} \mathrm{P}<0.05$ vs. the control group; ${ }^{\#} \mathrm{P}<0.05$ vs. cells treated with $5 \mathrm{mg} / \mathrm{ml}$ Trametes robiniophila. Bcl, B-cell lymphoma; Cas, caspase.

synthesis of Bcl-2 decreased. These results were consistent with the pattern of RT-PCR validation. The regulation was dose-dependent (Fig. 3).

\section{Discussion}

Generally, treatments for GC patients include surgery, radiotherapy and chemotherapy (17). Certain alternative treatments such as gene therapy and targeted therapy have also been proposed as optional treatment methods $(18,19)$. However, these therapies are usually costly for the majority of patients and have limited curative effect and serious side effects (20). In the past years, TCM, which has been widely used in China for thousands of years, has shown an anticancer potential 
effect (21). TCM has been demonstrated to reduce toxic side effects, improve the quality of life of patients, enhance the immune function, and prevent recurrence and metastasis in cancer patients, with few side effects (22). In the current study, AO/EB staining, flow cytometry and RT-PCR were conducted to detect the effect of Trametes robiniophila on the apoptosis and metastasis of the human GC cell line MKN-45. The results indicated that Trametes robiniophila changed the morphology and number of regular MKN-45 cells in a time- and dose-dependent manner, suggesting cell damage due to treatment with Trametes robiniophila (Figs. 1 and 2, Table II). Our results also demonstrated that Trametes robiniophila acts as an inducer of the apoptotic process in GC cells by influencing the expression of Fas, caspase-3 and $\mathrm{Bcl}-2$ (Figs. 2 and 3, Table III). However, the effect was significantly different between 5 and $10 \mathrm{mg} / \mathrm{ml}$. Considering the potential toxic effect of high doses of Trametes robiniophila on normal cells, $5 \mathrm{mg} / \mathrm{ml}$ should be taken as a reference for future clinical application.

Generally, apoptosis can be classified into two types: Apoptotic process mediated by the mitochondrial pathway and apoptotic process mediated by a membrane receptor signaling pathway (23). Caspase-3 is one of the key apoptosis executors, since the majority of factors that trigger apoptosis ultimately lead to apoptosis through the caspase-3-mediated signaling pathway $(24,25)$. Bcl-2, which is mainly distributed in the mitochondrial membrane and the cytoplasm, is an intracellular anti-apoptotic factor that can stabilize the mitochondrial membrane, prevent mitochondrial caspase release and inhibit the oxygen free radical-induced apoptosis signaling pathway (26). Fas can initiate the apoptotic process mediated by a membrane receptor by binding to Fas ligand, and can also recruit caspase-3 to induce apoptosis (27-30). Treatment with Trametes robiniophila suppressed $\mathrm{Bcl}-2$ expression and increased caspase-3 expression, which suggested a mitochondrial-mediated apoptosis. Additionally, the expression of Fas was also upregulated, indicating activation of the death receptor pathway of apoptosis. The results in the present study demonstrated that Trametes robiniophila could induce the apoptosis of GC cells by different mechanisms, whereas previously, only apoptosis induced by Trametes robiniophila via the mitochondrial pathway was reported (11).

The apoptosis observed in the present study was associated with downregulation of the expression of MMP-2 and MMP-9. Members of the MMP family are an integral part of the extracellular matrix's enzymatic arsenal and have been regarded as major critical molecules that assist tumor cells during metastasis (31). The expression of various MMPs has been observed to be upregulated in almost every type of human cancer, and correlates with advanced stage, invasive and metastatic properties, and, in general, with poor prognosis (32). Upon treatment with Trametes robiniophila, the expression of $M M P-2$ and $M M P-9$ was suppressed. The effect was dose dependent. Ji and Mai have revealed that the expression level of $M M P-2$ and $M M P-9$ was positively correlated with the metastatic ability of GC cells (33). In addition, a previous study has reported the inhibition of metastasis of lung cancer via the suppression of MMP-2 and MMP-9 (22). Therefore, Trametes robiniophila has the potential to regulate MMPs and can be considered a promising target for the therapeutic intervention in human cancer. Similarly to the majority of TCMs, Trametes robiniophila also has the advantage of few side effects and low cost compared with surgery, radiotherapy and chemotherapy (34).

Based on the present study, treatment with Trametes robiniophila could markedly induce the apoptosis of the human GC cell line MKN-45. The effect acted through both the mitochondrial and the member receptor signaling pathways. In addition, Trametes robiniophila could also suppress the metastatic ability of GC cells via downregulating the expression of $M M P-2$ and $M M P-9$. In conclusion, we recommend that Trametes robiniophila is taken into consideration as a noninvasive therapy of GC in future clinical treatment.

\section{References}

1. Parkin DM, Bray F, Ferlay J and Pisani P: Global cancer statistics, 2002. CA Cancer J Clin 55: 74-108, 2005.

2. Jemal A, Siegel R, Xu J and Ward E: Cancer statistics, 2010. CA Cancer J Clin 60: 277-300, 2010.

3. Shahrokh I: Gastric cancer as a multifactorial disease. Ann Mil Health Sci Res 11: 157-164, 2013.

4. Cunningham D, Allum WH, Stenning SP, Thompson JN, Van de Velde CJ, Nicolson M, Scarffe JH, Lofts FJ, Falk SJ, Iveson TJ, et al; MAGIC Trial Participants: Perioperative Chemotherapy versus surgery alone for resectable gastroesophageal cancer. New Engl J Med 355: 11-20, 2006.

5. Bang YJ, Kim YW, Yang HK, Chung HC, Park YK, Lee KH, Lee KW, Kim YH, Noh SI, Cho JY, et al; CLASSIC trial investigators: Adjuvant capecitabine and oxaliplatin for gastric cancer after D2 gastrectomy (CLASSIC): A phase 3 open-label, randomised controlled trial. Lancet 379: 315-321, 2012.

6. Monsuez JJ, Charniot JC, Vignat N and Artigou JY: Cardiac side-effects of cancer chemotherapy. Int J Cardiol 144: 3-15, 2010.

7. D'Angelica M, Gonen M, Brennan MF, Turnbull AD, Bains M and Karpeh MS: Patterns of initial recurrence in completely resected gastric adenocarcinoma. Ann Surg 240: 808-816, 2004.

8. Sagar SM, Yance D and Wong R: Natural health products that inhibit angiogenesis: A potential source for investigational new agents to treat cancer-Part 1. Current Oncol 13: 14-26, 2006.

9. Bhat TA and Singh RP: Tumor angiogenesis-a potential target in cancer chemoprevention. Food Chem. Toxicol. 46: 1334-1345, 2008.

10. Wu T, Chen W, Liu S, Lu H, Wang H, Kong D, Huang X, Kong Q, Ning Y and Lu Z: Huaier suppresses proliferation and induces apoptosis in human pulmonary cancer cells via upregulation of miR-26b-5p. FEBS Lett 588: 2107-2114, 2014.

11. Zhang F, Zhang Z and Liu Z: Effects of Huaier aqueous extract on proliferation and apoptosis in the melanoma cell line A875. Acta Histochem 115: 705-711, 2013.

12. Zhang T, Wang K, Zhang J, Wang X, Chen Z, Ni C, Qiu F and Huang J: Huaier aqueous extract inhibits colorectal cancer stem cell growth partially via downregulation of the Wnt/ $\beta$-catenin pathway. Oncol Lett 5: 1171-1176, 2013.

13. Guo Y, Cheng P and Chen Y: Isolation and analysis of the polysaccharide of Huaier mycelium. Zhong Guo Sheng Hua Yao Wu Za Zhi 63: 56-59, 1993 (In Chinese).

14. Guo Y, Cheng P and Chen Y: Studies on the constituents of polysaccharide from the hyphae of Trametes robiniophila (II)-identification of polysaccharide from the hyphae of Trametes robiniophila and determination of its molar ratio. Journal of China Pharmaceutical University 23: 155-157, 1992.

15. Zhang F, Zhang ZY and Liu Z: Effects of Huaier aqueous extract on proliferation and apoptosis in the melanoma cell line A875. Acta Histochemica 115: 705-711, 2013.

16. Zhu J, Li X, Kong X, Moran MS, Su P, Haffty BG and Yang Q: Testin is a tumor suppressor and prognostic marker in breast cancer. Cancer Sci 103: 2092-2101, 2012.

17. Hartgrink HH, Jansen EP, van Grieken NC and van de Velde CJ: Gastric cancer. Lancet 374: 477-490, 2009.

18. Wu Y, Wang W, Chen Y, Huang K, Shuai X, Chen Q, Li X and Lian G: The investigation of polymer-siRNA nanoparticle for gene therapy of gastric cancer in vitro. Int $\mathrm{J}$ Nanomedicine 5: 129-136, 2010.

19. Wang TT, Qian XP and Liu BR: Survivin: Potential role in diagnosis, prognosis and targeted therapy of gastric cancer. World J Gastroenterol 13: 2784-2790, 2007. 
20. Li HW, Yang JK and Zhao AG: Adjuvant therapy for gastric cancer. Shijie Huaren Xiaohua Zazhi 22: 4921-4927, 2014 (In Chinese).

21. Song X, Li Y, Zhang $\mathrm{H}$ and Yang Q: The anticancer effect of Huaier (Review). Oncol Rep 34: 12-21, 2015.

22. Hu B, Du Q, Shen K and Xu L: Principles and scientific basis of traditional Chinese medicine in cancer treatment. J Bioanal Biomed S6: 2, 2012.

23. Salahudeen A K, Huang H, Joshi M, Moore NA and Jenkins JK Involvement of the mitochondrial pathway in cold storage and rewarming-associated apoptosis of human renal proximal tubular cells. Am J Transplant 3: 273-280, 2003.

24. Rao RV, Hermel E, Castro-Obregon S, del Rio G, Ellerby LM Ellerby HM and Bredesen DE: Coupling endoplasmic reticulum stress to the cell death program mechanism of caspase activation. J Biol Chem 276: 33869-33874, 2001.

25. Jin L, Amatya VJ, Takeshima Y, Shrestha L, Kushitani K and Inai K: Evaluation of apoptosis and immunohistochemical expression of the apoptosis-related proteins in mesothelioma. Hiroshima J Med Sci 59: 27-33, 2010.

26. Bagci E, Vodovotz Y, Billiar T, Ermentrout G and Bahar I: Bistability in apoptosis: Roles of bax, bcl-2 and mitochondrial permeability transition pores. Biophys J 90: 1546-1559, 2006.

27. Hu D, Wang S and Feng Y: Expression of matrix metalloproteinase-7 and Fas and their significances in gastric carcinoma. Shi Jie Hua Ren Xiao Hua Za Zhi 14: 3237, 2006 (In Chinese).
28. Morimoto Y, Hizuta A, Ding EX, Ishii T, Hongo T, Fujiwara T, Iwagaki $\mathrm{H}$ and Tanaka N: Functional expression of Fas and Fas ligand on human intestinal intraepithelial lymphocytes. Clin Exp Immunol 116: 84-89, 1999.

29. Wang L, Wang YR and Yang J: Significance of integrin $\beta \_3$ expression in human hemangioma $(\mathrm{J})$. Chinese Journal of Aesthetic Medicine 5: 031, 2009.

30. Cai Cf, Feng L, Wang L, Kong QZ and Zhao YF: Tetrazolium violet induces apoptosis via caspases-8, -9 activation and Fas/FasL up-regulation in Rat C6 glioma cells. Arch Pharm Res 32: 575-581, 2009.

31. Rucci N, Sanità P and Angelucci A: Roles of metalloproteases in metastatic niche. Curr Mol Med 11: 609-622, 2011.

32. Hesek D, Toth M, Meroueh SO, Brown S, Zhao H, Sakr W, Fridman R and Mobashery S: Design and characterization of a metalloproteinase inhibitor-tethered resin for the detection of active MMPs in biological samples. Chem Biol 13: 379-386, 2006.

33. Ji DL and Mai DH: Effect of huaier granule on immunity and quality of life in patients with gastric cancer undergoing postoperative concurrent radiochemotherapy. Zhong Guo Zhong Liu 19: e6, 2010 (In Chinese).

34. Song XY, Ying-Dong LI, Shi YP, Jin L and Chen J: Quality control of traditional Chinese medicines: A review. Chin J Nat Med 11: 596-607, 2013. 